\title{
The ecological cleanliness of milk and products of its processing when using the sorption-probiotic supplement in the diet of cows
}

\author{
Vasily E. Ulitko*, Svetlana P. Lifanova, Lidia A. Pykhtina, and Oksana E. Erisanova \\ Ulyanovsk State Agrarian University, Ulyanovsk 432017, Russia
}

\begin{abstract}
In the study, in the conditions of the dairy complex of the agricultural Firm Tetyushskoe in the Ulyanovsk region, five groups of cows (26 heads per group) were fed according to detailed standards. Cows of groups II, III, IV and V were fed a new sorption-probiotic Supplement (SPD) Biopinnular at a dose of $0.25 ; 0.50 ; 0.75$ and $1.00 \%$ of dry matter. SPD was made from the natural mineral diatomite (sorbent) and probiotic microbiota (Bacillus subtilius). Such a formulation reduces impact on the body of endo- and exotoxins, in the digestive tract inhibits the development of pathogenic and stimulates the proliferation of lactic acid bacteria and bifidobacteria, enhances the digestibility and assimilation of nutrients, for exceeds efficiency and productivity of cows, improve the sustainability of milk and its products. On 100 EKE fed, $7.88,12.54,3.73$ and $3.48 \%$ more milk was obtained from cows of the experimental groups than from control cows $(63.86 \mathrm{~kg})$. The highest efficiency of the diet was observed in group III. The SPD corrects the environmental friendliness of milk and its processing products. The concentration of $\mathrm{Pb}$ and $\mathrm{Cd}$ in them did not exceed the MPC and was dependent on the dose of the fed Supplement. The least effective dose for reducing ecotoxicants in products was $0.25 \%$. Therefore, to increase the efficiency of the diet and reduce ecotoxicants content in dairy products, it is advisable to use SPD in diets at a dose of $0.50 \%$ of dry matter.
\end{abstract}

\section{Introduction}

Intensive industrial agricultural production often leads to a breaking the natural content of organic and mineral substances in the food chain, as well as to accumulation of unusual chemical compounds.

In the context of industrial dairy complexes, the problem of safe and high-quality milk production and its products is currently becoming especially important due to contamination of fodder and water consumed by cows with toxic elements.

In modern conditions of human life, special attention must be paid to the control and quality of food products, including milk and its processed products. Heavy metals enter animal milk as a result of their accumulation in food chains. These elements contained in the exhaust gases of cars cause contamination of the surface of the soil and plants. Also, high concentrations of toxic elements such as lead and cadmium in the air can cause direct contamination of both milk and dairy products.

Their accumulation in their body leads to deterioration in the ecological cleanliness of milk and products of its processing, which subsequently poses serious hazards through food products to humans [1].

A special group of toxic substances is made up of heavy metals such as cadmium and lead salts and ions, as they weaken the activity of the animal's basic systems in the organism and cause various diseases. Milk from such cows does not meet the requirements of GOST (the state standard) due to the high content of eco-toxicants, does not have sufficient producibility and poses a threat to human health [2-4].

In this regard, to improve the safety and ecological cleanliness of milk and its processed products, it is most effective to use local natural minerals in cow feeding, which due to their nanoporous structure possess adsorption properties [5-7].

Large deposits of natural mineral diatomite with such properties were found in the Ulyanovsk region. Taking this into account, the objective of this work was to develop a new feed supplement "Biopinnular" (Technical conditions 10.91.10-003-84275297-2020). The preparation is named after diatomaceous alga pinnaria (Pinnularia) and was developed on the basis of natural mineral diatomite and probiotic bacteria (Bacterius subtilius).

The research is also aimed at clarifying the preparation's effect in the diets of cows as it manifests in their productivity and assumed improvement in the safety and environmental cleanliness of milk and dairy products.

\section{Materials and research methods}

In experimental studies in the conditions of the industrial dairy complex of LLC Agrofirm Tetyushskoye of the 
Ulyanovsk region, five similar groups [8] of highly productive black and white cows (26 animals per group) were fed with detailed diets [9]. In this case, the cows of the experimental groups received in their diet different doses of the sorption-probiotic supplement "Biopinnular". The experimental design is presented in table 1 .

Table 1. Design of the experiment

\begin{tabular}{|c|c|l|}
\hline Group & $\begin{array}{c}\text { Number } \\
\text { of cows }\end{array}$ & \multicolumn{1}{c|}{ Feeding conditions } \\
\hline I-C+ & 26 & $\begin{array}{l}\text { MD* - according to detailed diet } \\
\text { formulations of the All-Russian } \\
\text { Institute of Animal husbandry }\end{array}$ \\
\hline II-E** & 26 & $\begin{array}{l}\text { MD+ the sorption-probiotic } \\
\text { supplement "Biopinnular" 0,25 \% } \\
\text { of the dry matter of the diet }\end{array}$ \\
\hline III-E & 26 & $\begin{array}{l}\text { MD+ the sorption-probiotic } \\
\text { supplement "Biopinnular" 0,50 \% } \\
\text { of the dry matter of the diet }\end{array}$ \\
\hline IV-E & 26 & $\begin{array}{l}\text { MD+ the sorption-probiotic } \\
\text { supplement "Biopinnular" 0,75 \% } \\
\text { of the dry matter of the diet }\end{array}$ \\
\hline V-E & 26 & $\begin{array}{l}\text { MD+ the sorption-probiotic } \\
\text { supplement "Biopinnular" 1,00 \% } \\
\text { of the dry matter of the diet }\end{array}$ \\
\hline
\end{tabular}

$+\mathrm{C}-$ control group, ${ }^{* *} \mathrm{E}-$ experimental groups, ${ }^{*} \mathrm{MD}-$ main diet.

The biological effect of the feed supplement based on diatomite is achieved, first of all, by its porosity containing up to 40 macro-microelements and a large porosity at the nanostructured level. This determines the adsorption of mycotoxins, heavy metals and radionuclides contained in feeds, and probiotic bacteria added in its composition inhibit the development of pathogenic microorganisms in the digestive tract and activate the reproduction of lactobacilli and bifidobacteria, which reduces the toxicological load on the body and improves digestion of nutrients received from a diet.

In view of this, an increase in the efficiency of consumed feeds is ensured, and, consequently, not only an increase in the productivity of cows, but also the quality (ecological cleanliness) of the dairy products is improved. The concept of ecology and food safety of milk and products of its processing as environmentally clean products embraces the idea of reducing the presence of substances that can be introduced from the environment [10-12].

In the experiment, during a 3-month lactation, averaged samples of milk were obtained from 4 to 5 cows (as per GOST 13928-84) for research in the laboratory of the Ulyanovsk state agrarian University named after P. A. Stolypin.

In the laboratory, the following parameters were determined according to standard techniques and using modern instruments: mass fraction of fat (GOST 586790) on the device "Clover 2"; mass fraction of protein (on the device "Clover 2"); density, using a hydrometer according to GOST 3625-84; dry substance according to GOST 3626-73; SOMO GOST 3626-73; lactose content and energy value of milk according to GOST calculation method.

The content of heavy metals (lead and cadmium) in milk and dairy products was monitored during the scientific and economic experiment for 4-5 cows from each group in the third or fourth month of their lactation as reflecting the characteristic of the whole period of lactation activity.

The studies were carried out by spectrometry on a Quant-Z-ETA instrument in the testing laboratory of the P.A. Stolypin Ulyanovsk State Agrarian University. The study materials were processed statistically using the MS Office-2003 software.

\section{Research results}

The materials summarized in Table 2 show that the inclusion of sorption-probiotic supplements in different doses into the diet of cows has an unambiguous effect on the efficiency of diets, the manifestation of their milk productivity and the ecological cleanliness of milk and its processed products.

Analyzing the indicators of milk productivity, we can see that it was $7.89 \%$ higher in cows of the experimental groups (II, III, IV and IV); 12.56; 3.73 and $3.46 \%$ higher in the mass fraction of fat, respectively, by $4.14 \%$; 3.99; 4.09 and $4.06 \%$, than in cows of the control group $(2887.80 \mathrm{~kg}$ with a fat content of $3.92 \%)$.

Moreover, according to these indicators, cows of groups II and III were superior to cows of other experimental groups.

Therefore, the sorption-probiotic supplement enhances the extent of fermentation of nutritive substances of the diet in the rumen and, in particular, the activity of bacteria that ferment fiber, which is accompanied by the formation of acetic acid in a large quantity as the main source for formation of the milk fat.

An increase in the protein content in the milk of the cows of the experimental groups is an indirect evidence of not only higher ammonia cleaving in their rumen, but also the ammonia-binding activity of the bacteria forming a complete microbiological protein.

As a result, more milk fat of $13.22 \ldots 18.55 \mathrm{~kg}$ and protein of $7.81 \ldots 11.31 \mathrm{~kg}$ was obtained from the cows of the experimental groups compared to the control. As a result, the productive effect of the feed in a diet increases.

For every $100 \mathrm{EFU}$ (energetic feed unit) of the feed fed more milk was obtained from cows in the experimental groups by $7.88 ; 12.54 ; 3.73$ and $3.48 \%$ than from animals in the control group $(63.86 \mathrm{~kg})$. As we can see, the greatest productive effect of the consumed feeds of the diet is manifested when the sorptionprobiotic supplement is used in its composition with doses 0.25 and $0.50 \%$ of the dry matter.

As for the presence of heavy metals in the milk of cows and dairy products, in the compared groups their content did not exceed the MPC. At the same time, feeding cows with the test doses of sorption-probiotic feed supplements as a part of the diet reduces the content of lead and cadmium in milk and its processed products. 
Table 2. Milk productivity of cows and the content of heavy metals in milk and products of its processing

\begin{tabular}{|c|c|c|c|c|c|c|}
\hline \multirow[t]{2}{*}{ Name of the product } & \multicolumn{5}{|c|}{ Group } & \multirow{2}{*}{$\begin{array}{l}\text { MPC } \\
\mathrm{mg} / \mathrm{kg}\end{array}$} \\
\hline & I-C & II-E & III-E & IV-E & V-E & \\
\hline \multicolumn{7}{|c|}{ Productivity indicators } \\
\hline Milk yield per cow, $\mathrm{kg}$ & 2887.80 & 3115.63 & 3250.43 & 2995.58 & 2987.80 & - \\
\hline in $\%$ to control & 100.0 & 107.89 & 112.56 & 103.73 & 103.46 & - \\
\hline $\begin{array}{l}\text { Weight content of fat in } \\
\text { milk, } \%\end{array}$ & $3.92 \pm 0.08$ & $4.14 \pm 0.06^{*}$ & $3.99 \pm 0.02$ & $4.09 \pm 0.05^{*}$ & $4.06 \pm 0.11$ & - \\
\hline $\begin{array}{l}\text { Weight content of protein } \\
\text { in milk, \% }\end{array}$ & $3.0 \pm 0.04$ & $3.12 \pm 0.03 *$ & $3.01 \pm 0.02$ & $3.06 \pm 0.02 *$ & $3.04 \pm 0.4$ & \\
\hline $\begin{array}{l}\text { Weight content of lactose } \\
\text { in milk, \% }\end{array}$ & $4.44 \pm 0.03$ & $4.45 \pm 0.02$ & $4.44 \pm 0.02$ & $4.48 \pm 0.03$ & $4.51 \pm 0.03$ & \\
\hline Energy value of milk, kcal & 639.3 & 669.6 & 649.7 & 658.5 & 668.0 & \\
\hline $\begin{array}{l}\text { Milk obtained for } 100 \\
\text { EFU, kg }\end{array}$ & 63.86 & 68.89 & 71.87 & 66.24 & 66.08 & - \\
\hline \multicolumn{7}{|c|}{ Heavy metal content } \\
\hline \multicolumn{7}{|c|}{ lead, $\mathrm{mg} / \mathrm{kg}$} \\
\hline Milk & $\begin{array}{c}0.09228 \pm \\
0.00717\end{array}$ & $\begin{array}{l}0.08236 \pm \\
0.00272\end{array}$ & $\begin{array}{l}0.07079 \pm \\
0.00334 *\end{array}$ & $\begin{array}{c}0.06749 \pm \\
0.00326^{* *}\end{array}$ & $\begin{array}{c}0.05225 \pm \\
0.00447 * * *\end{array}$ & 0,1 \\
\hline in $\%$ to control & 100.0 & 89.25 & 76.71 & 73.14 & 56.62 & \\
\hline Milk whey & $\begin{array}{c}0.08161 \pm \\
0.00278\end{array}$ & $\begin{array}{c}0.08094 \pm \\
0.00339\end{array}$ & $\begin{array}{c}0.07662 \pm \\
0.00304\end{array}$ & $\begin{array}{c}0.06999 \pm \\
0.00216^{* *}\end{array}$ & $\begin{array}{c}0.06648 \pm \\
0.00256^{* * *}\end{array}$ & 0,1 \\
\hline in $\%$ to control & 100.0 & 99.18 & 93.89 & 85.76 & 81.46 & \\
\hline Butter & $\begin{array}{c}0.10483 \pm \\
0.00531\end{array}$ & $\begin{array}{c}0.09854 \pm \\
0.00381\end{array}$ & $\begin{array}{l}0.09144 \pm \\
0.00338 *\end{array}$ & $\begin{array}{l}0.07900 \pm \\
0.00720 *\end{array}$ & $\begin{array}{l}0.07270 \pm \\
0.00625 * *\end{array}$ & 0,1 \\
\hline in $\%$ to control & 100.0 & 93.99 & 87.22 & 75.36 & 69.35 & \\
\hline Curds & $\begin{array}{c}0.02279 \pm \\
0.00105\end{array}$ & $\begin{array}{c}0.02089 \pm \\
0.00172\end{array}$ & $\begin{array}{l}0.01877 \pm \\
0.00160 *\end{array}$ & $\begin{array}{l}0.01755 \pm \\
0.00138^{*}\end{array}$ & $\begin{array}{c}0.01593 \pm \\
0.00124 * *\end{array}$ & 0,3 \\
\hline in $\%$ to control & 100.0 & 91.66 & 89.85 & 84.01 & 76.26 & \\
\hline \multicolumn{7}{|c|}{ cadmium, mg/kg } \\
\hline Milk & $\begin{array}{c}0.01116 \pm \\
0.00042\end{array}$ & $\begin{array}{l}0.00975 \pm \\
0.00093\end{array}$ & $\begin{array}{c}0.00859 \pm \\
0.00031^{* *}\end{array}$ & $\begin{array}{c}0.00829 \pm \\
0.00039 * *\end{array}$ & $\begin{array}{c}0.00797 \pm \\
0.00057^{* *}\end{array}$ & 0,03 \\
\hline in $\%$ to control & 100.0 & 87.37 & 76.97 & 74.28 & 71.42 & - \\
\hline Milk whey & $\begin{array}{c}0.01448 \pm \\
0.00064\end{array}$ & $\begin{array}{l}0.01281 \pm \\
0.00054\end{array}$ & $\begin{array}{l}0.01217 \pm \\
0.00058^{*}\end{array}$ & $\begin{array}{c}0.01113 \pm \\
0.00040^{* *}\end{array}$ & $\begin{array}{c}0.00960 \pm \\
0.00030^{* * *}\end{array}$ & 0,03 \\
\hline in $\%$ to control & 100.0 & 88.47 & 84.05 & 76.87 & 66.30 & \\
\hline Butter & $\begin{array}{c}0.01202 \pm \\
0.00045\end{array}$ & $\begin{array}{l}0.01199 \pm \\
0.00112\end{array}$ & $\begin{array}{c}0.00947 \pm \\
0.00060^{* *}\end{array}$ & $\begin{array}{c}0.01004 \pm \\
0.00055^{* *}\end{array}$ & $\begin{array}{c}0.00853 \pm \\
0.00106^{* *}\end{array}$ & 0,03 \\
\hline in $\%$ to control & 100.0 & 99.75 & 78.79 & 83.53 & 70.97 & \\
\hline Curds & $\begin{array}{c}0.00579 \pm \\
0.00092\end{array}$ & $\begin{array}{l}0.00423 \pm \\
0.00075\end{array}$ & $\begin{array}{c}0.00364 \pm \\
0.00062\end{array}$ & $\begin{array}{l}0.00322 \pm \\
0.00069 *\end{array}$ & $\begin{array}{l}0.00306 \pm \\
0.00065^{*}\end{array}$ & 0,2 \\
\hline in $\%$ to control & 100.0 & 73.06 & 62.87 & 55.61 & 52.85 & \\
\hline
\end{tabular}

$* \mathrm{P}<0.05 ; * * \mathrm{P}<0.01 ; * * * \mathrm{P}<0.001$

In the milk of cows of the compared groups, the concentration of lead was in direct dependence on the feeding dose of the feed supplement "Biopinnular" in the diet, while the degree of its excretion relative to the control group was $10.75 \%$ in the second group, $23.29 \%$ in the third, in the fourth $-26.86 \%$ and $-43.38 \%$ in the fifth.

The cadmium concentration in the milk of the cows of the compared groups also did not exceed the maximum permissible concentration, however, its content in the milk of the cows of groups II, III, IV, and $\mathrm{V}$ depended on the dose of the sorption-probiotic supplement used in the diet and amounted to 87, $37 \%$ $76.97 ; 74.28$ and $71.42 \%$ of its concentration in the milk of cows of the control group.

Monitoring that have been carried out showed that not only in milk and, but also in products of its processing (butter, curds, milk whey), the content of lead and cadmium did not go beyond the MPC, while their content in these products varied depending on the feeding dose of sorption-probiotic supplements.

The least influence on the decrease in the content of these toxic metals, both in milk and dairy products, was 
exerted with the dose of the sorption-probiotic supplement at $0.25 \%$ of the dry matter in the diet.

Therefore, the inclusion of the sorption-probiotic feed supplement "Biopinnular" in diets of cows in the amount of $0.25 ; 0.50 ; 0.75$ and $1.00 \%$ of its dry matter provides not only an improvement digestive and metabolic processes (enhances the depth and changes the direction of enzymatic processes in the rumen and assimilation processes in their body).

It reduces the toxicological load, makes it possible to obtain clean milk and its processed products by reducing the accumulation of lead and cadmium in them, in milk by $10.75 \ldots .43 .48$ and $12.63 \ldots 28.58 \%$ respectively, in butter lead by $6.01 \ldots 30.65 \%$, cadmium by $0.25 \ldots .29 .03$ $\%$ and in curds lead by $8.34 \ldots 24.74 \%$ and cadmium by 26.94...47.85\%. In this case, the least pronounced effect on the decrease in lead and cadmium in milk and products of its processing is exerted by the sorptionprobiotic supplement included in the diet at a dose of $0.25 \%$ of its dry matter.

\section{Conclusion}

To reduce the level of eco-toxicants in milk of cows and products of its processing, it is expedient to use the sorption-probiotic feed supplement "Biopinnular" in animals' diets. The preparation also increases milk productivity due to the optimization of microbiocenosis in the gastrointestinal tract, reducing toxicological load on the body, enhancing enzymatic processes in the rumen, and this ensures a greater intake of nutrient substrates in the blood, strengthening metabolic processes including the mammary gland, thus ultimately improving the safety and cleanliness of milk and its products.

It was found that for $100 \mathrm{EKE}$ of fed feed from cows of the experimental groups, $7.88 ; 12.54 ; 3.73$ and $3.48 \%$ more milk was obtained than from control cows $(63.86 \mathrm{~kg})$. At the same time, the highest efficiency of feed ration is shown when it includes $0.50 \%$ sorptionprobiotic additives.

Of all the tested doses, the least effective for reducing ecotoxicants in milk and its processed products was a dose of $0.25 \%$.

Thus, to increase the efficiency of feed ration and reduce the amount of ecotoxicants in cow milk and its processing products, it is advisable to use the sorptionprobiotic Supplement Biopinular in rations at a dose of $0.50 \%$ of its dry matter.

\section{References}

1. V.E. Ulitko, S.P. Lifanova, O.E. Erisanova, Raising stress resistance of cows, their productivity and nutritional value of milk when using antioxidant supplements in diets, Bull. of the Ulyanovsk State Agricult. Acad. 2(46), 197-200 (2019)

2. S.A. Zarvanskaya, N.A. Shkaev, M.V. Kalmykov, V.A. Budarkov, L.M. Surgucheva, Yu.B. Kudryashov, E.N. Goncharenko, The use of a sorbent to reduce the transfer of radionuclides from feeds to milk, Practitioner 11-12, 38-41 (2003)

3. A.A. Morozenko, A.V. Tyulkov, T.I. Yukanova, V.V. Yukhanov, A.I. Sotnichenko, Application of the feed supplement "Alvisorb" in lactating cows, Veter. Med. 2, 28-33 (2018)

4. O.V. Okhrimenko, G.N. Zabegalova, Sorbents for improving the quality of raw milk for butter production, Cheesemak. and buttermak. 3, 48 (2008)

5. O.A. Desyatov, S.P. Lifanova, Milk productivity and digestion processes in the rumen of cows when using a nanostructured, silicon-containing preparation "Biocoretron-forte" in their diets, in: Mater. of the II Int. sci. and pract. Conf. of young scientists Youth and science: reality and future, vol. VIII, pp. 267269 (Nevinnomyssk, 3 March 2009)

6. E.Yu. Tarasova, E.I. Petrova, Ecological aspects of the quality of dairy products, in: Proc. of the XIV Int. sci. and pract. Conf. Food. Ecology. Quality, pp. 242-245 (2017)

7. V.F. Pozdnyakova, O.V. Latysheva, The influence of the sorbent "Simbitox" on milk production of cows, Zootechn. 4, 17-19 (2019)

8. A.I. Ovsyannikov, Fundamentals of experimental work in animal husbandry (Kolos, Moscow, 1976) 302 p.

9. A.P. Kalashnikov, Norms and rations for feeding farm animals: a reference guide (Moscow, 2003) $486 \mathrm{p}$.

10. A.P. Tereshchenko, M.A. Verotchenko, The distribution of heavy metals between the constituent parts of milk, in: Int. sci. conf. Ecological and genetic problem of animal husbandry and environmental safety of food production technology (1998) $108 \mathrm{p}$.

11. G.M. Topuria, L.Yu. Topuria, Ecology and quality of milk, Bull. of the Orenburg State University 6(62), 227-229 (2016)

12. M.I. Chernyak, Heavy metals in dairy products (contamination of Ossetian cheese and sweet cream butter), Ecolog. safety in the agro-industrial complex. Abstract J. 4, 771 (2000) 